NBER WORKING PAPERS SERIES

TIME-VARYING VOLATILITY AND THE DYNAMIC BEHAVIOR OF THE TERM STRUCTURE

Robert F. Engle

Victor $\mathrm{K}$. Ng

Working Paper No. 3682

NATIONAL BUREAU OF ECONOMIC RESEARCH

1050 Massachusetts Avenue

Cambridge, MA 02138

April 1991

The authors are grateful to Jim Bodurtha, Angelo Melino, Michael Rothschild, Ken Singleton and participants at the UCSD

conference: Statistical Models for Financial Volatility for helpful comments on an earlier draft of this paper. This paper is part of NBER's research program in Financial Markets and Monetary Economics. Any opinions expressed are those of the authors and not those of the National Bureau of Economic
Research. 
NBER Working Paper $\# 3682$ April 1991

TIME-VARYING VOLATILITY AND THE DYNAMIC BEHAVIOR OF THE TERM STRUCTURE

\begin{abstract}
In this paper, we consider a framework with which the cross sectional and time series behavior of the yield curve can be studied simultaneously. We examine the relationship between the yield curve and the time-varying conditional volatility of the Treasury bill market. We demonstrate that differently shaped yield curves can result given different combinations of volatility and expectations about future spot rates. Moreover, adjusting the forward rate for the volatility related liquidity premium can improve its performance as a predictor of future spot rates at least for the period from August 1964 to August 1979.

Robert F. Engle Chairman and Professor Department of Economics University of California, San Diego

La Jolla, CA 92093

Victor $\mathrm{K}$. Ng

Assistant Professor of Finance

School of Business Administration University of Michigan Ann Arbor, MI 48109-1234
\end{abstract}




\title{
TIME-VARYING VOLATILITY AND THE DYNAMIC BEHAVIOR OF THE TERM STRUCTURE
}

\author{
Robert F. Engle, Professor of Economics \\ University of California, San Diego \\ Victor K. Ng, Assistant Professor of Finance \\ University of Michigan, Ann Arbor
}

February, 1991

\section{I: INTRODUCTION}

Much research has been done in the term structure literature about the existence and the variability of term and liquidity premia. For example, Fama (1984a) and McCulloch (1987) have examined the existence and the monotonicity of term premia. McCulloch (1975) and Fama (1984b) have examined the existence of liquidity premia. Campbell (1987), Engle, Lilien and Robins (1987), Lauterbach (1989) and Engle, Ng and Rothschild (1990) have examined the time variability of term premia. Of course, since term premia and liquidity premia are related, results on one can indeed be translated into results about the other. ${ }^{1}$ To summarize the empirical results in terms of the term premia, the literature has generally found: (1) the term premia are non-zero, and (2) the term premia are time-varying.

These results have important implications for the term structure. For instance, the existence of term premia and the fact that they are time-varying mean that the movements of the yield curve over time are driven not only by changes in the expectations

1

Term premium is defined as the difference between the expected one period holding return of a long bond and the sure one period return of a one period bond. Liquidity premium is traditionally defined as the difference between the forward rate and the expected future spot rate. The relationship between term premium and liquidity premium is given in 
about future one period interest rates but also by changes in the term premia. Moreover, the shape of the yield curve is also changing over time. The exact shape of the yicld curve depends on the expectations about future interest rates as well as the expectations about future movements of the term premia. Lastly, since the existence of time-varying term premia implies the existence of time varying liquidity premia, the forward rate is not an unbiased forecast of the future spot rate.

What is not yet clear is the exact nature of these non-zero time-varying term premia (and liquidity premia) and their dynamic behavior. It was argued in the traditional Liquidity Preference. Theory that term premia exist because lenders prefer the liquidity provided by short term bonds. Hence, to induce them to purchase long term bonds, extra rewards have to be offered. Under the Liquidity Preference Theory, changes in the term premia over time should be related to changes in the liquidity preference of investors in the bond markets. Modern portfolio theory however suggests that it is also possible to have risk related term premia. In that case, changes in the term premia over time would be related to changes in the riskiness of the bonds over time.

In a recent paper, Engle $-\mathrm{Ng}-$ Rothschild (1990) (hereafter ENR) examine formally the second possibility. They consider a one factor model for the excess returns on Treasury bills of two to twelve months maturity in which the factor (a equally weighted bill portfolio) itself has changing variance. The ENR model can be viewed as a special case of the Asset Pricing Theories developed by Merton (1973), Ross (1976) and Breeden (1979). In the ENR model, the factor risk premium is a linear function of the conditional volatility of the factor. Hence the term premia and the liquidity premia will change over time as volatility changes. Consequently, both the position and the shape of the yield curve should change over time as volatility changes. ENR shows that their one factor model passes a variety of diagnostic tests and compares favorably with previous empirical findings. Given

section II and is derived in the appendix. 
the empirical success of the ENR model, it is interesting to examine in more detail the economic implications of the model and how it might help answer some of the existing puzzles in the term structure literature. As such, the purpose of this paper is not really providing new statistical tests for the adequacy of the ENR model as much as providing a new angle from which to view the evidence. Specifically, we want to address the follow questions: (1) Can the ENR model generate plausible shapes for the yield curve? (2) What is the effect of a change in bill market volatility on the position and shape of the yield curve? And (3) Will the premium adjusted forward rates provide good forecasts for future spot rates?

We address questions (1) and (2) in section III via simulation experiments. The results indicate that the ENR model can produce a large set of differently shaped yield curves including the puzzling hump shape. The analysis also suggests various qualitative results regarding the relationship between the shape of the yield curve and the level of volatility. In particular, the premium component is important relative to the expectation component when volatility is very high. Hence the yield curve can be monotonically increasing even though the spot rates are expected to be decreasing. On the other hand, when volatility is low, the premium component is unimportant relative to the expectation component and hence a monotonically decreasing yield curve could be produced if the spot rate is expected to drop. For medium volatility levels, the exact shape of the yield curve depends crucially on the tradeoff between the expectation component and the premium component.

We address question (3) in section IV. We examine the preformance of the ENR predictor for future spot rates. As in Fama(1976), we use the predictive performance of past spot rates as a benchmark. We found that for the period before the 1979 change in the Federal Reserve operating procedure, the adjusted forward rates provide as good predictions about fut ure spot rates as the past spot rates. We also notice that the adjusted forward 
rates perform better in short horizon prediction than in long horizon prediction. We attribute this to a decline in the quality of multiperiod variance forecasts (which are required for the adjustments to forward rates for long horizon predictions) when we lengthen the forecasting horizon. The predictive performance of the adjusted forward rates are not good for the whole sample period from 1964 to 1985 . The problem might come from severe over adjustment during the 1979-1982 period when the bill market is extraordinarily volatile. It is likely that the change in operating procedure by the Federal Reserve in 1979 did produce a structural change in the behavior of the bill market.

Analyses in section IV use the same dataset as in Engle, $\mathrm{Ng}$, and Rothschild (1990) with the addition of corresponding yields to maturity and forward rates data. The dataset contains monthly returns, yields to maturity, and corresponding forward rates for Treasury bills with maturities ranging from one to twelve months as well as the monthly returns of a NYSE+AMEX value weighted stock portfolio. The Treasury bill data is obtained from the Fama Term Structure File in the 1985 CRSP Government Bond Tape. The stock data is obtained from the 1985 CRSP Index Tape. The sample period is from August 1964 to November 1985 .

We will start off with a short review on the relationships among yields, term premia, forward rates and liquidity premia as well as a review of the ENR model in the next section. Readers familiar with both can start with section III. 


\section{II: A MODEL, FOR THE TERM PREMIUMS}

Let $R_{t}^{(n)}$ and $R_{t}^{(1)}$ be the one period holding returns from time $t-1$ to time $t$ investing in pure discount bonds with $n$-period and 1 -period to maturity, respectively. Also let $\mathrm{E}_{\mathrm{t}}(\cdot)$ be the expectation operator given all information available at time $t$. The term premium of an $n$-period pure discount bond at time $t, \mu_{t}^{(n)}$, is defined as

$$
\mu_{\mathrm{t}}^{(\mathrm{n})} \equiv \mathrm{E}_{\mathrm{t}-1}\left(\mathrm{R}_{\mathrm{t}}^{(\mathrm{n})}\right)-\mathrm{R}_{\mathrm{t}}^{(1)}
$$

From forward substitution the yield to maturity at time $t, r_{t}^{(n)}, 2$ of an $n$-period pure discount bond is just the average of the subsequently realized holding returns or

$$
r_{t}^{(n)}=\frac{1}{n} \sum_{j=1}^{n} R_{t+j}^{(n-j+1)} .
$$

Since this identity must hold in expectation and since $r_{t}^{(n)}$ is in the information set at time $t$, the yield to maturity can be related to the term premia according to ${ }^{3}$

$$
\begin{aligned}
r_{t}^{(n)}=E_{t}\left(A_{t+1}^{(n)}\right)+E_{t}\left(T_{t+1}^{(n)}\right) & \\
\text { where, } \quad A_{t+1}^{(n)} & \equiv \frac{1}{n} \sum_{j=0}^{n-1} r_{t+j}^{(1)} \\
T_{t+1}^{(n)} & \equiv \frac{1}{n} \sum_{j=1}^{n} \mu_{t+j}^{(n-j+1)}
\end{aligned}
$$

The first term on the right hand side of equation (2), $E_{t}\left(A_{t+1}^{(n)}\right)$, is the expectation component of the yield to maturity. It is the conditional expectation of average future

By definition, the yield to maturity of a one period discount bond at time $t$, denoted by $r_{t}^{(1)}$, is equal to the one period holding return of the one period bond from time $t$ to time $t+1$, denoted by $R_{t+1}^{(1)}$. 
one-period spot rates. The modelling of this component has received a lot of attention in traditional term structure research to which Dobson, Sutch, and Vanderford (1976) gave a very good review. The second term, $E_{t}\left(T_{t+1}^{(n)}\right)$ is the term premium component of the yield to maturity. If term premia are time varying then there will be changes in both the position and the shape of the yield curve which are not explained by changes in the expectations of the future one-period spot rate.

The one period forward rate at time $t, f_{t}^{(n)}$, for the period from time $t+n-1$ to time $t+n$, is also related to the term premia. Based on (2), the equation for the forward rate is:

$$
f_{t}^{(n)}=E_{t}\left(r_{t+n-1}^{(1)}\right)+\left[n \cdot E_{t}\left(T_{t+1}^{(n)}\right)-(n-1) \cdot E_{t}\left(T_{t+1}^{(n-1)}\right)\right]
$$

The first term on the right hand side of equation (3) is the expected one period spot rate from time $t+n-1$ to time $t+n$. The liquidity premium, $L_{t}^{(n)}$, which is traditionally defined as the difference between the forward rate and the expected future spot rate is therefore given by:

$$
L_{t}^{(n)} \equiv n \cdot E_{t}\left(T_{t+1}^{(n)}\right)-(n-1) \cdot E_{t}\left(T_{t+1}^{(n-1)}\right)
$$

Again, if term premia are non-zero and time-varying then liquidity premia will be non-zero and time-varying. Hence, the forward rate will not be an unbiased predictor of the future one period spot rate. ${ }^{4}$

Equations (2), (3), and (4) show that to understand the term structure, it is very important to understand the nature and the dynamic behavior of the the term premia. ENR considers the possibility that the term premia are risk related and is related to the volatility of a single factor. The key characteristics of the ENR model can be summarized by the diagram below:

3

A simple derivation of equation (2) is given in the appendix.

1

The unbiased expectation hypothesis in the term structure literature postulates that the 


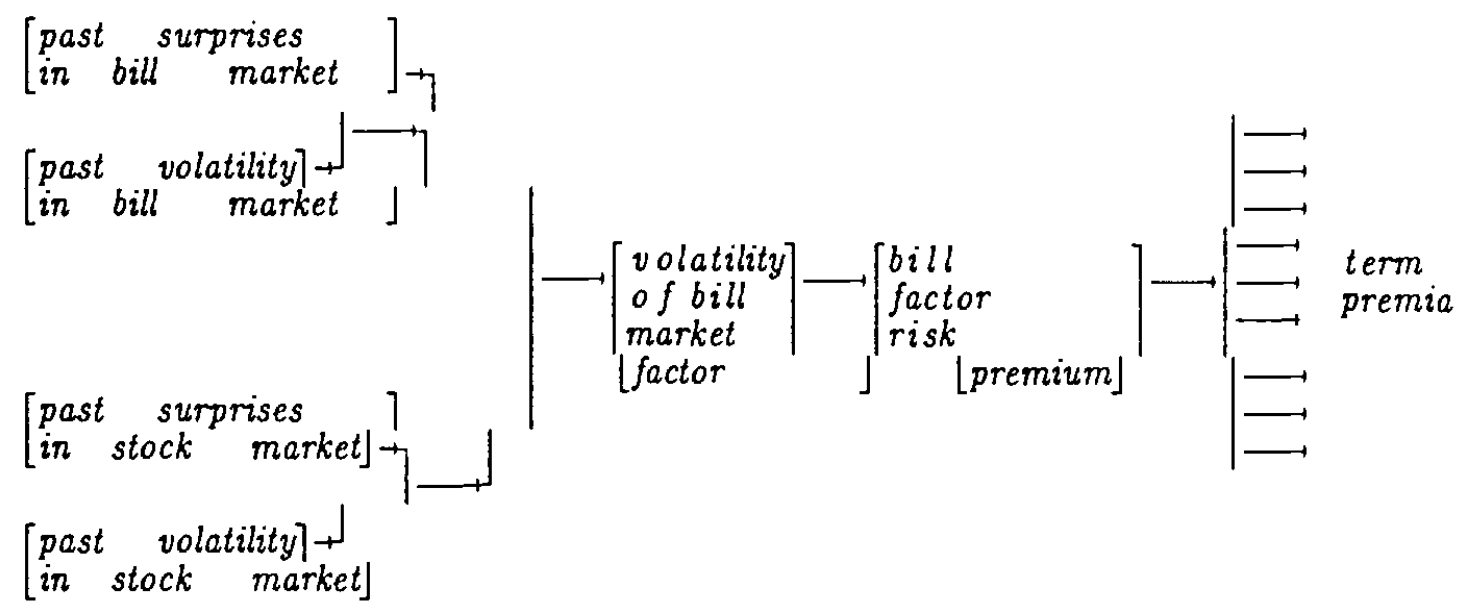

The ENR model postulates:

[1] The term premium of a Treasury bill is driven by the timevarying risk premium of an equally weighted bill portfolio representing an unobservable bill market factor.

[2] The time-varying risk premium of the bill portfolio is driven by the time-varying conditional variance of the bill portfolio itself.

[3] The conditional variance of the bill portfolio is a function of the past return innovations and conditional variance of the bill portfolio itself as well as the past return innovations and conditional variance of a value weighted stock portfolio representing an unobservable stock market factor.

The model explicitly allows the time varying conditional volatility of a bill market factor to determine the dynamic behavior of the term premia. It also allows the past

liquidity premium is zero and hence the forward rate is an unbiased predictor of future spot rates. 
innovations and conditional volatility of a stock market factor to affect the term premia indirectly through their influence on bill market volatility. ${ }^{5}$

Let $P_{b t}, \Pi_{b t}$ and $\theta_{b t}$ be the excess return, risk premium and conditional excess return variance at time $t$ of the equally weighted bill portfolio respectively. Also let $P_{s t}$ ' $\Pi_{s t}$ and $\theta_{\text {st }}$ be the excess return, risk premium and conditional excess return variance at time $t$ of the value weighted stock portfolio respectively. Model description [1] can be represented specifically by the equation:

$$
\mu_{\mathrm{t}}^{(\mathrm{n})}=\Psi^{(\mathrm{n})}+\beta_{\mathrm{b}}^{(\mathrm{n})} \cdot \Pi_{\mathrm{bt}}
$$

where, $\beta_{\mathrm{b}}^{(\mathrm{n})}$ is the factor loading of a Treasury bill with $\mathrm{n}$ months to maturity on the bill market factor. And, $\Psi^{(n)}$ is the time invariant portion of the risk premium of the $\mathrm{n}-$ month bill. This kind of pricing equation is in the spirit of the arbitrage pricing theory of Ross (1976), the intertemporal CAPM of Merton (1973), and the consumption beta model of Breeden (1986). A simple justification of this pricing relationship is also given in the appendix of ENR (1990) and in Campbell (1987). The remaining model description, [2] and [3], can be represented by the following set of equations:

$$
\begin{aligned}
& \Pi_{\mathrm{bt}} \equiv \mathrm{E}_{\mathrm{t}-1}\left(\mathrm{P}_{\mathrm{bt}}\right)=\mathrm{c}_{\mathrm{b}}+\gamma_{\mathrm{b}} \cdot \theta_{\mathrm{bt}} \\
& \Pi_{\mathrm{st}} \equiv \mathrm{E}_{\mathrm{t}-1}\left(\mathrm{P}_{\mathrm{st}}\right)=\mathrm{c}_{\mathrm{s}}+\gamma_{\mathrm{s}} \cdot \theta_{\mathrm{st}} \\
& \theta_{\mathrm{st}} \equiv \mathrm{Var}_{\mathrm{t}-1}\left(\mathrm{P}_{\mathrm{st}}\right)=\omega_{\mathrm{s}}+\phi_{\mathrm{ss}} \cdot \mathrm{u}_{\mathrm{st}-1}^{2}+\varphi_{\mathrm{ss}} \cdot \theta_{\mathrm{st}-1} \\
& \theta_{\mathrm{bt}} \equiv \mathrm{Var}_{\mathrm{t}-1}\left(\mathrm{P}_{\mathrm{bt}}\right)=\omega_{\mathrm{b}}+\phi_{\mathrm{bb}} \cdot \mathrm{u}_{\mathrm{bt}-1}^{2}+\varphi_{\mathrm{bb}} \cdot \theta_{\mathrm{bt}-1} \\
& \quad+\phi_{\mathrm{bs}} \cdot \mathrm{u}_{\mathrm{st}-1}^{2}+\varphi_{\mathrm{bs}} \cdot \theta_{\mathrm{st}-1}
\end{aligned}
$$

5ENR did not find any direct influence from stock market volatility to the term premia. They have estimated and tested a two factor model using a value-weighted stock portfolio as an additional factor. The addition is not supported by the data. 
Equations (6) and (7) define the factor risk premia and relate risk premia to conditional volatility. This specification is motivated by Campbell (1987), French, Schwert, and Stambaugh (1987), and Engle, Lilien, and Robins (1987). Equations (8) and (9) allow past innovations of bill portfolio and stock portfolio excess returns to affect their conditional variances. This relationship is suggested by the ARCH model of Engle (1982) and Bollerslev (1986). The specification can be interpreted as a VAR model for the squared residuals of the bill portfolio excess return and the stock portfolio excess return.

The complete model as described by equations (5) through (9) is estimated by ENR using the holding period returns data described in section I. Since most of the analyses in this paper are based on the results in ENR, we have included in table I below the parameter estimates in their paper for the sake of completeness. ${ }^{6}$

Table I

Estimation results for equation (6), (7), (8), and (9)

$$
\begin{aligned}
& \Pi_{\mathrm{st}}=\frac{-3.376}{(-1.5)}+\underset{(1.58)}{0.1982 \cdot \theta_{\mathrm{st}}} \\
& \theta_{\mathrm{st}}=\underset{(1.68)}{1.9348}+\underset{(1.79)}{0.0518 \cdot \mathrm{u}_{\mathrm{st}-1}^{2}}+\underset{(12.6)}{0.8461 \cdot \theta_{\mathrm{st}-1}} \\
& \Pi_{b t}=\underset{(0.28)}{0.0046}+\underset{(4.00)}{0.6965 \cdot \theta_{b t}} \\
& \theta_{\mathrm{bt}}=\underset{(-2.4)}{-0.031}+\underset{(4.17)}{0.2997 \cdot \mathrm{u}_{\mathrm{bt}-1}^{2}}+\underset{(8.98)}{0.5996 \cdot \theta_{\mathrm{bt}-1}} \\
& +\underset{(0.97)}{0.0002 \cdot u_{s t-1}^{2}}+\frac{0.0021 \cdot \theta_{s t-1}}{(2.37)}
\end{aligned}
$$

(Asymptotic $t-$ statistics are in parentheses)

6

Engle, $\mathrm{Ng}$ and Rothschild (1989) use a two step estimation procedure. The procedure involve estimating the conditional variance of the bill and stock portfolio excess returns in the first step and then estimate the equation for individual bill excess return using the estimated bill and stock portfolio conditional variances as predetermined variables in the second step. Lin (1989) gives a detailed comparison of this method (two step univariate GARCH) to three other estimation procedures, namely, ML, restricted ML and two step ML. The procedure of Engle, $\mathrm{Ng}$ and Rothschild give consistent estimates for the parameters of interest. However, Lin (1989) show that the estimated standard errors are 
Estimation results for equation (5)

\begin{tabular}{|c|c|c|}
\hline $\mathrm{n}$ & $\Psi^{(n)}$ & $\beta_{\mathrm{b}}^{(\mathrm{n})}$ \\
\hline $\begin{array}{c}2 \\
3 \\
4 \\
5 \\
6 \\
7 \\
8 \\
9 \\
10 \\
11 \\
12\end{array}$ & $\begin{array}{l}0.0139 \\
0.0213 \\
0.0181 \\
0.0121 \\
0.0008 \\
-0.007 \\
-0.1452 \\
-0.005 \\
-0.079 \\
-0.009 \\
-0.063 \\
-0.48 \\
-0.045 \\
-0.049 \\
-0.28 \\
-0.45 \\
-2.86 \\
-1.89 \\
-1.89\end{array}$ & $\begin{array}{l}0.1802 \\
0.3460 \\
0.5249 \\
0.7300 \\
0.8890 \\
0.9979 \\
1.165 \\
1.1657 \\
1.3597 \\
28.16 \\
1.6206 \\
1.7162 \\
1.74 \\
1.9212 \\
24.16 \\
25.84 \\
25.83 \\
26.61 \\
23.00\end{array}$ \\
\hline
\end{tabular}

(Asymptotic $t-$ statistics are in parentheses)

Yield and liquidity premium

Based on equations (7) and (9), equation (5) for the term premium can be rewritten as a function of the past innovations and conditional volatilities of the bill market factor and the stock market factor as follows:

$$
\begin{aligned}
\mu_{t}^{(n)}= & \Psi \\
& +\beta_{b}^{(n)} c_{b}+\beta_{b}^{(n)} \gamma_{b} \omega_{b} \\
& +\beta_{b}^{(n)} \gamma_{b}\left[\phi_{b b} u_{b t-1}^{2}+\varphi_{b b} o_{b t-1}+\phi_{b s} u_{s t-1}^{2}+\varphi_{b s}{ }_{s t-1}\right]
\end{aligned}
$$

Using equations (8), (9) and (10), the equation for yield and the equation for liquidity premium can be rewritten as functions of the conditional volatilities of the bill and stock portfolio excess returns. The equation for the yield to maturity is

$$
r_{t}^{(n)}=E_{t}\left(A_{t+1}^{(n)}\right)+T^{(n)}+K_{s}^{(n)}\left[0_{s t+1}-\bar{\partial}_{s}\right]+K_{b}^{(n)}\left[0_{b t+1}-\partial_{b}\right]
$$

where,

$$
T^{(n)}=C^{(n)}+K_{s}^{(n)} \partial_{s}+K_{b}^{(n)} \partial_{b}
$$

generally biased upward. Hence the $t$-tests for the parameter estimates are conservative. 


$$
\begin{aligned}
& C^{(n)}=\frac{1}{n} \sum_{j=2}^{n}\left[\Psi^{(j)}+\beta_{b}^{(j)} c_{b}\right]+\frac{1}{n} \cdot\left[\sum_{j=1}^{n-1} \beta_{b}^{(n-j+1)} \gamma_{b} \cdot\left(\underline{I}_{b}{ }^{\prime} \Gamma_{j} \underline{w}\right)\right] \\
& K_{s}^{(n)}=\frac{1}{n} \cdot\left[\sum_{j=1}^{n-1} \beta_{b}^{(n-j+1)} \gamma_{b} \cdot\left(\underline{I}_{-b}{ }^{\prime} G^{j-1} I_{-s}\right)\right] \\
& K_{b}^{(n)}=\frac{1}{n} \cdot\left[\sum_{j}^{n-1} \beta_{b}^{(n-j+1)} \gamma_{b} \cdot\left(\underline{I}_{b}{ }^{j}{ }^{j-1} \underline{I}_{b}\right)\right] \\
& \partial_{s}=E\left(0_{s t+1}\right) \text { is the unconditional mean of } \theta_{s t+1} \\
& \partial_{\mathrm{b}}=\mathrm{E}\left(\mathrm{O}_{\mathrm{bt}+1}\right) \text { is the unconditional mean of } 0_{\mathrm{bt}+1}
\end{aligned}
$$

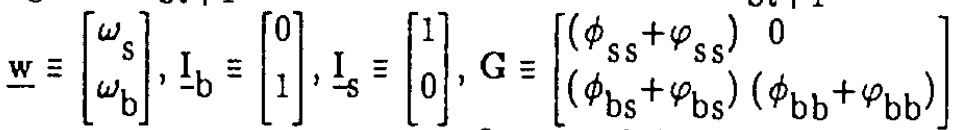

$$
\begin{aligned}
& \Gamma_{1} \equiv 0, \Gamma_{2} \equiv I, \quad \Gamma_{j} \equiv I+G+G^{2}+\cdots+G^{j-2}(j>2)
\end{aligned}
$$

The equation for the liquidity premium is

$$
\text { where, } \quad \begin{array}{ll}
L_{t}^{(n)}= & L^{(n)}+\ell_{s}^{(n)} \cdot\left[0_{s t+1}-0_{s}\right]+\ell_{b}^{(n)} \cdot\left[0_{b t+1}-0_{b}\right] \\
& L^{(n)}=n \cdot T^{(n)}-(n-1) \cdot T^{(n-1)} \\
& d_{s}^{(n)}=n \cdot K_{s}^{(n)}-(n-1) \cdot K_{s}^{(n-1)} \\
& \ell_{b}^{(n)}=n \cdot K_{b}^{(n)}-(n-1) \cdot K_{b}^{(n-1)}
\end{array}
$$

The first term on the right hand side of the yield equation is the expectation component of yield-to-maturity, the second term is the time invariant part of the term premium component. The sum of the first and second terms on the right hand side gives the yield-to-maturity when the stock and bill portfolio conditional volatilities are at their unconditional mean levels. The remaining two terms on the right hand side give the effects of having the conditional volatilities deviate from the mean volatility levels. The equation for liquidity premium has a similar interpretation. The first term on the right hand side of the liquidity premium equation gives the level of liquidity premium when stock and bill conditional volatilities are at their mean levels. The other two terms give the effects of having stock and bill conditional volatilities deviate from their mean levels. 
Using the parameter estimates in Table I from ENR (1990), the parameters in the yield equation (11) and the liquidity premium equation (12) are computed. They are reported in table II below:

Table II

\begin{tabular}{rllllll}
\hline $\mathrm{n}$ & $\mathrm{T}^{(\mathrm{n})}$ & $\mathrm{K}_{\mathrm{s}}^{(\mathrm{n})}$ & $\mathrm{K}_{\mathrm{b}}^{(\mathrm{n})}$ & $\mathrm{L}^{(\mathrm{n})}$ & $\mathrm{d}_{\mathrm{s}}^{(\mathrm{n})}$ & $\ell_{\mathrm{b}}^{(\mathrm{n})}$ \\
\hline 2 & .014851 & .000000 & .06275 & .029703 & .000000 & .12550 \\
3 & .027141 & .000096 & .11795 & .051720 & .000288 & .22835 \\
4 & .036448 & .000268 & .17095 & .064367 & .000784 & .32995 \\
5 & .044475 & .000507 & .22468 & .076585 & .001463 & .43960 \\
6 & .050316 & .000810 & .27158 & .079521 & .002325 & .50608 \\
7 & .054789 & .001159 & .30863 & .081630 & .003253 & .53093 \\
8 & .060279 & .001532 & .34435 & .098706 & .004143 & .59439 \\
9 & .066018 & .001926 & .38049 & .111926 & .005078 & .66961 \\
10 & .067553 & .002344 & .42083 & .081374 & .006106 & .78389 \\
11 & .071267 & .002794 & .45271 & .108407 & .007294 & .77151 \\
12 & .075552 & .003254 & .48471 & .122678 & .008314 & .83671 \\
\hline
\end{tabular}

\section{III: THE SHAPE OF THE YIELD CURVE}

Given the yield equation (11), the liquidity premium equation (12) and the parameter estimates in the table II, we can ask: (1) Whether or not this model can generate yield curves of the commonly observed shapes? And (2) What is the relationship between the level of volatility and the position and shape of the yield curve? To answer theses questions, we perform some simulation experiments. Below, we will give a description of the experiments and their implications.

\section{Description of the computational experiments}

Since the shape of the yield curve is determined jointly by expectations about future spot rates (which we haven't modelled up to this point) and expectations about future term premia (which are given by the last three terms on the right hand side of equation (11)), two set of experiments are conducted. In the first set, we focus on the term premium effect. 
We consider a scenario in which future spot rates are expected to stay at the current level. In other words, the one period spot rate is assumed to follow a simple random walk process without drift. Under this assumption the shape of the yield curve is determined solely by the term premium component. In the second set, we manage to study how interaction between the expectation component, $E_{t}\left(A_{t+1}^{(n)}\right)$, and the term premium component, $E_{t}\left(T_{t+1}^{(n)}\right)$, could produce a richer set of yield curves. For the ease of demonstration, We consider a scenario in which the one period spot rate follows a simple random walk with drift. ${ }^{7}$ The analyses are as follows:

\section{$\underline{\text { Scenario } 1}$}

The one period spot rate is a simple random walk without drift:

$$
\begin{aligned}
& r_{t}^{(1)}=r_{t-1}^{(1)}+\epsilon_{t} \\
& \quad \text { (where } \epsilon_{t} \text { is a mean zero random noise) }
\end{aligned}
$$

The expectation part, $E_{t}\left(A_{t+1}^{(n)}\right)$ is equal to $r_{t}^{(1)}$ for all $n$. Hence, the shape of the yield curve is determined solely by the premium:

$$
E_{t}\left(T_{t+1}^{(n)}\right)=T^{(n)}+K_{s}^{(n)} \cdot\left[\theta_{s t+1}-\partial_{s}\right]+K_{b}^{(n)} \cdot\left[\theta_{b t+1}-\partial_{b}\right]
$$

To see what kind of yield curve is available, the value of this term premium part is computed for different levels of stock and bill market conditional volatility. We have considered five different cases. First, both stock and bill conditional volatilities are set at their highest levels observed in the sample. Second, stock volatility is set at its sample average level and bill volatility is set at its highest in-sample level. Third, both stock and bill volatility are set at their sample average levels. Fourth, stock volatility is set at its sample average level and bill volatility is set at its lowest level in sample. Fifth, both stock and bill volatility are set at their lowest in-sample levels. The results are given in table III below:

7

The choice of the random walk model for the expectation component is mainly for the ease of demonstration. The theme of this paper is on the modelling of the term premium component rather than the modelling of the expectaion component. Readers interested in the later can take a look at Dobson, Sutch and Vanderford (1976) and Melino (1983). Both 


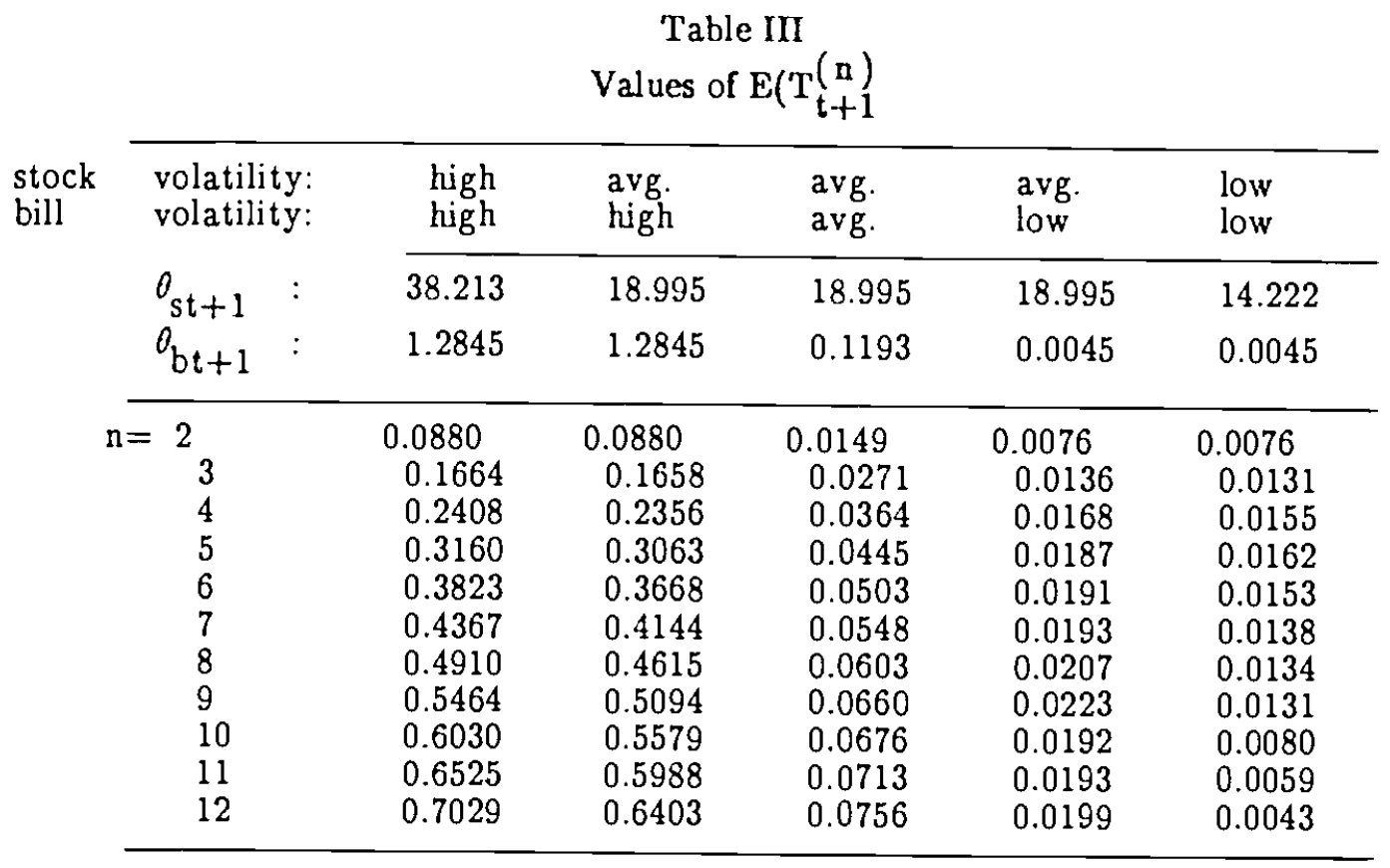

The results indicate that even under a random walk assumption, the yield curve can still take either monotonic or humped shape. Under normal or high volatility levels, the yield curve will be upward sloping. However, under low volatility levels, the yield curve can have humped shape. Where the yield curve will peak depends crucially on the level of volatility. The lower the level of volatility, the earlier it will peak. Even under the high volatility case, the rate of increase diminishes as a function of maturity introducing curvature in to the term structure.

Of course, since the shape of the yield curve is determined jointly by the expectation component and the term premium component, adding the effect from the expectation component will give us a even richer set of yield curves. Adding the expectation component also allows us to assess the role played by each of the components and their relative importance. This is the remaining part of the experiment:

papers give good survey on earlier works on expectation formation. 


\section{$\underline{\text { Scenario } 2}$}

The one period spot rate is assumed to follow:

$$
r_{t}^{(1)}=r_{t-1}^{(1)}+\delta+\epsilon_{t}
$$

where, $\delta$ is the drift and $\epsilon_{t}$ is a random noise with mean zero.

To study how yield curves of different shapes can be generated under different combinations of the expectation part and the premium part we consider ten possible regimes each with a different combination of the drift term in the random walk, stock volatility and bill volatility. To understand the difference between an expected increase in the spot rate and an expected decrease in the spot rate, the analysis is done with positive drift as well as temporary negative drift ${ }^{8}$. The results are given in table IV below:

\begin{tabular}{|c|c|c|c|c|c|c|}
\hline \multirow{4}{*}{$\begin{array}{l}\text { stock } \\
\text { bill }\end{array}$} & \multicolumn{6}{|c|}{$\begin{array}{c}\text { Table IV } \\
\text { Values of } r_{t}(n) \\
r_{t}^{(1)}=0.5, \delta=0.005\end{array}$} \\
\hline & $\begin{array}{l}\text { volatility: } \\
\text { volatility: }\end{array}$ & $\begin{array}{l}\text { high } \\
\text { high }\end{array}$ & $\begin{array}{l}\text { avg. } \\
\text { high }\end{array}$ & $\begin{array}{l}\text { avg. } \\
\text { avg. }\end{array}$ & $\begin{array}{l}\text { avg. } \\
\text { low }\end{array}$ & $\begin{array}{l}\text { low } \\
\text { low }\end{array}$ \\
\hline & $0_{s t+1}:$ & 38.213 & 18.995 & 18.995 & 18.995 & 14.222 \\
\hline & $\mathrm{O}_{\mathrm{bt}+1}:$ & 1.2845 & 1.2845 & 0.1193 & 0.0045 & 0.0045 \\
\hline $\mathrm{n}=$ & $\begin{array}{l}2 \\
3 \\
4 \\
5 \\
6 \\
7 \\
8 \\
9 \\
10 \\
11 \\
12\end{array}$ & $\begin{array}{l}0.5905 \\
0.6714 \\
0.7483 \\
0.8260 \\
0.8948 \\
0.9517 \\
1.0085 \\
1.0664 \\
1.1255 \\
1.1775 \\
1.2304\end{array}$ & $\begin{array}{l}0.5905 \\
0.6696 \\
0.7431 \\
0.8163 \\
0.8793 \\
0.9294 \\
0.9790 \\
1.0294 \\
1.0804 \\
1.1238 \\
1.1678\end{array}$ & $\begin{array}{l}0.5174 \\
0.5321 \\
0.5439 \\
0.5545 \\
0.5628 \\
0.5698 \\
0.5778 \\
0.5860 \\
0.5901 \\
0.5963 \\
0.6031\end{array}$ & $\begin{array}{l}0.5101 \\
0.5186 \\
0.5243 \\
0.5287 \\
0.5316 \\
0.5343 \\
0.5382 \\
0.5423 \\
0.5417 \\
0.5443 \\
0.5474\end{array}$ & $\begin{array}{l}0.5101 \\
0.5181 \\
0.5230 \\
0.5262 \\
0.5278 \\
0.5288 \\
0.5309 \\
0.5331 \\
0.5305 \\
0.5309 \\
0.5318\end{array}$ \\
\hline
\end{tabular}

8

In principle, the process for the spot rate cannot have a permanent negative drift as this would imply a negative interest rate in the long run. However, it is perfectly valid to have 


\begin{tabular}{|c|c|c|c|c|c|c|}
\hline \multirow{5}{*}{$\begin{array}{l}\text { stock } \\
\text { bill }\end{array}$} & \multicolumn{6}{|c|}{$\begin{array}{c}\text { Values of } r_{t}(n) \\
r_{t}^{(1)}=0.5, \delta=-0.007\end{array}$} \\
\hline & $\begin{array}{l}\text { volatility: } \\
\text { volatility: }\end{array}$ & $\begin{array}{l}\text { high } \\
\text { high }\end{array}$ & $\begin{array}{l}\text { avg. } \\
\text { high }\end{array}$ & $\begin{array}{l}\text { avg. } \\
\text { avg. }\end{array}$ & $\begin{array}{l}\text { avg. } \\
\text { low }\end{array}$ & $\begin{array}{l}\text { low } \\
\text { low }\end{array}$ \\
\hline & $\theta_{s t+1}:$ & 38.213 & 18.995 & 18.995 & 18.995 & 14.222 \\
\hline & $0_{b t+1}:$ & 1.2845 & 1.2845 & 0.1193 & 0.0045 & 0.0045 \\
\hline & 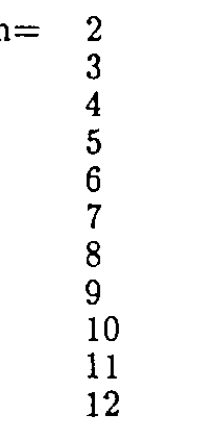 & $\begin{array}{l}0.5845 \\
0.6594 \\
0.7303 \\
0.8020 \\
0.8648 \\
0.9157 \\
0.9665 \\
1.0184 \\
1.0715 \\
1.1175 \\
1.1644\end{array}$ & $\begin{array}{l}0.5845 \\
0.6576 \\
0.7251 \\
0.7923 \\
0.8493 \\
0.8934 \\
0.9370 \\
0.9814 \\
1.0264 \\
1.0638 \\
1.1018\end{array}$ & $\begin{array}{l}0.5114 \\
0.5201 \\
0.5259 \\
0.5305 \\
0.5328 \\
0.5338 \\
0.5358 \\
0.5380 \\
0.5361 \\
0.5363 \\
0.5371\end{array}$ & $\begin{array}{l}0.5041 \\
0.5066 \\
0.5063 \\
0.5047 \\
0.5016 \\
0.4983 \\
0.4962 \\
0.4943 \\
0.4877 \\
0.4843 \\
0.4814\end{array}$ & $\begin{array}{l}0.5041 \\
0.5061 \\
0.5050 \\
0.5022 \\
0.4978 \\
0.4928 \\
0.4889 \\
0.4851 \\
0.4765 \\
0.4709 \\
0.4658\end{array}$ \\
\hline
\end{tabular}

The numbers given in table IV have some interesting implications. First of all, even when the spot rate is drifting up, it is still possible to have a hump shaped yield curve provided that volatility is low enough and the positive drift is not too big. Secondly, when volatility is very high, the term premium part can be more important than the expectation part in terms of magnitude. Indeed, even when the spot rate is drifting down, it is still possible to have an upward sloping yield curve provided that volatility is high enough. Thirdly, during a period in which the spot rate is drifting down, even an average level of volatility can produce a humped shape yield curve. Actually, where exactly the yield curve will peak depends on the direction and magnitude of the drift as well as the levels of stock and bill market volatilities. Given the same volatility levels, the faster the spot rate drifts down, the earlier the yield curve will peak. With a very big negative drift, the yield curve will simply be downward sloping. On the other hand, given the same drift, the higher the

a negative drift term for a short time period. 
volatility levels, the later the yield curve will peak. With very high levels of volatility in the stock market and the bill market, the yield curve will simply be upward sloping. Moreover, bill market volatility seems to be more important than stock market volatility in determining the shape and position of the yield curve.

\section{IV: PREDICTING FUTURE SPOT RATES}

The usefulness of forward rates as predictors of future spot rates has received much attention in the term structure literature. Generally, the forward rates contain not only information about expectations on future spot rates but also "premia" related to either risk or liquidity. As we have demontrated in the second section, unless these premia are properly controlled for, the forward rates are not unbiased predictors for future spot rates. Since the ENR model relates the term premia and hence the liquidity premia to volatility, whether we can get better forecasts of future spot rates by adjusting the forward rates for the time-varying liquidity premium given by the ENR model is an interesting question. In fact, since the ENR model treats term premia as "risk" premia, the usefulness of adjusting for "risk-based" liquidity premia might also give us some idea about the nature of the premia. To answer this question, we first look at the ability of the ENR model to explain the difference between the subsequent realization of the short rate and the $n$-period ahead forward rate. The equation we consider in our regression analysis is as follow:

$$
f_{t}^{(n)}-r_{t+n-1}^{(1)}=a_{0}+a_{1} \cdot L_{t}^{(n)}+e_{t+n-1}^{(n)}
$$

On the left hand side of the above regression equation, we have the difference between the current forward rate and the future spot rate. On the right hand side are a constant term, the liquidity premium predicted by the ENR model, and a mean zero random error term. The liquidity premia are computed using equation (12) and the corresponding parameter 
estimates given in table II.

Under the null hypothesis that the ENR model is appropriate, the $\mathrm{a}_{0}$ coefficients should be zero and the $a_{1}$ coefficients should equal one for all $n$. The regression results for equation (16) are presented in table $\mathrm{V}$ below.

\begin{tabular}{|c|c|c|c|c|}
\hline \multirow[b]{3}{*}{$\mathrm{n}$} & \multicolumn{4}{|c|}{$\begin{aligned} & \text { Table V } \\
&=a_{0}+a_{1} \cdot L_{t}^{(n)}+e_{t+n-1}^{(n)}\end{aligned}$} \\
\hline & \multicolumn{2}{|c|}{$64 / 8-79 / 8$} & \multicolumn{2}{|c|}{$64 / 8-85 / 11$} \\
\hline & $a_{0}$ & $a_{1}$ & $a_{0}$ & $a_{1}$ \\
\hline 2 & $\begin{array}{l}-0.0037 \\
(0.015)\end{array}$ & $\begin{array}{r}1.0885 \\
(0.631)\end{array}$ & $\begin{array}{l}-0.0058 \\
(0.008)\end{array}$ & $\begin{array}{r}1.1853 \\
(0.206)\end{array}$ \\
\hline 3 & $\begin{array}{l}-0.0202 \\
(0.017)\end{array}$ & $\begin{array}{r}1.5707 \\
(0.400)\end{array}$ & $\begin{array}{r}0.0163 \\
(0.013)\end{array}$ & $\begin{array}{r}0.7555 \\
(0.194)\end{array}$ \\
\hline 4 & $\begin{array}{l}-0.0196 \\
(0.014)\end{array}$ & $\begin{array}{r}1.4178 \\
(0.273)\end{array}$ & $\begin{array}{r}0.0386 \\
(0.017)\end{array}$ & $\begin{array}{r}0.3453 \\
(0.190)\end{array}$ \\
\hline 5 & $\begin{array}{l}-0.0170 \\
(0.020)\end{array}$ & $\begin{array}{r}1.4283 \\
(0.312)\end{array}$ & $\begin{array}{r}0.0593 \\
(0.024)\end{array}$ & $\begin{array}{r}0.2376 \\
(0.204)\end{array}$ \\
\hline 6 & $\begin{array}{l}-0.0053 \\
(0.020)\end{array}$ & $\begin{array}{r}1.2023 \\
(0.290)\end{array}$ & $\begin{array}{r}0.0703 \\
(0.026)\end{array}$ & $\begin{array}{r}0.0947 \\
(0.202)\end{array}$ \\
\hline 7 & $\begin{array}{l}-0.0101 \\
(0.023)\end{array}$ & $\begin{array}{r}1.3035 \\
(0.325)\end{array}$ & $\begin{array}{r}0.0725 \\
(0.029)\end{array}$ & $\begin{array}{r}0.0268 \\
(0.214)\end{array}$ \\
\hline 8 & $\begin{array}{l}-0.0047 \\
(0.027)\end{array}$ & $\begin{array}{r}1.1236 \\
(0.317)\end{array}$ & $\begin{array}{r}0.0877 \\
(0.033)\end{array}$ & $\begin{array}{r}0.0597 \\
(0.208)\end{array}$ \\
\hline 9 & $\begin{array}{l}-0.0110 \\
(0.030)\end{array}$ & $\begin{array}{r}1.0584 \\
(0.302)\end{array}$ & $\begin{array}{r}0.0848 \\
(0.038)\end{array}$ & $\begin{array}{r}0.1049 \\
(0.210)\end{array}$ \\
\hline 10 & $\begin{array}{l}-0.0104 \\
(0.020)\end{array}$ & $\begin{array}{r}1.0421 \\
(0.245)\end{array}$ & $\begin{array}{r}0.0566 \\
(0.037)\end{array}$ & $\begin{array}{r}0.1154 \\
(0.199)\end{array}$ \\
\hline 11 & $\begin{array}{l}-0.0158 \\
(0.028)\end{array}$ & $\begin{array}{r}0.9078 \\
(0.267)\end{array}$ & $\begin{array}{r}0.0672 \\
(0.042)\end{array}$ & $\begin{array}{r}0.0526 \\
(0.207)\end{array}$ \\
\hline 12 & $\begin{array}{l}-0.0094 \\
(0.053)\end{array}$ & $\begin{array}{c}0.5744 \\
(0.442)\end{array}$ & $\begin{array}{r}0.0656 \\
(0.053)\end{array}$ & $\begin{array}{l}-0.0642 \\
(0.236)\end{array}$ \\
\hline
\end{tabular}

(The numbers in parentheses are asymptotic standard errors with the Hansen-Hodrick autocorrelation correction)

The results indicate that for the period before the change in operating procedure by the Federal Reserve in 1979, the liquidity premium implied by the ENR model can well explain the difference between the forward rate and the expost future spot rate. The coefficient $a_{0}$ is insignificantly different from zero for all maturities. Also, the coefficient $a_{1}$ is 
significantly different from zero and insignificantly different from one for all maturities. However, the regression results for the full sample period including periods before and after the 1979 change are poor. The coefficient $a_{1}$ is significantly different from zero only for maturities from two to five months. Moreover, it is significantly different from one for all maturities. The risk related liquidity premium implied by the ENR model does have some explanatory power for the difference between the forward rate and the expost future spot rate. However, the magnitude is far from being close to the prediction of the model.

The above results suggest that at least for the period before the change in operating procedure by the FED, adjusting the forward rates for the liquidity premia implied by the ENR model should give us better forecasts for the future spot rates. What is not clear is how much better? To assess whether or not the adjustment is important economically we have computed the $R-$ squares of three different regressions: (1) a regression of future spot rate on current spot rate, (2) a regression of future spot rate on the corresponding forward rate computed from the current yield curve, and (3) a regression of future spot rate on the forward rate which is adjusted for the liquidity premium implied by the ENR model. The liquidity premium is computed based on equation (12) and the parameter estimates in table II. The regressions are performed for different forecasting horizons and the R-squares are reported in table VI below. 
Table VI

\begin{tabular}{|c|c|c|c|c|c|c|c|}
\hline \multicolumn{2}{|c|}{$\begin{array}{l}\text { Regression[1]: } \\
\text { Regression[2]: } \\
\text { Regression[3]: }\end{array}$} & \multicolumn{3}{|c|}{$\begin{array}{l}r_{t+n-1}^{(1)}=\text { Const } \\
r_{t+n-1}^{(1)}=\text { Const } \\
r_{t+n-1}^{(1)}=\text { Const }\end{array}$} & \multicolumn{3}{|c|}{$\begin{array}{l}+b_{1} \cdot r_{t}^{(1)}+e_{1 t+n-1} \\
+b_{2} \cdot f_{t}^{(n)}+e_{2 t+n-1}\end{array}$} \\
\hline \multirow[b]{2}{*}{$\mathrm{n}$} & \multirow{2}{*}{$\begin{array}{l}1964 / 8 \\
2[1)]\end{array}$} & \multicolumn{2}{|c|}{$-1979 / 8$} & & \multicolumn{3}{|c|}{$1964 / 8-1985 / 12$} \\
\hline & & $\mathrm{R}^{2}[2]$ & $\mathrm{R}^{2}[3$ & 1 & $\mathrm{R}^{2}[1]$ & $\mathrm{R}^{2}[2]$ & $\mathrm{R}^{2}[3]$ \\
\hline 2 & 0.884 & 0.859 & 0.863 & & 0.894 & 0.897 & 0.902 \\
\hline 3 & 0.815 & 0.762 & 0.781 & & 0.817 & 0.812 & 0.806 \\
\hline 4 & 0.749 & 0.734 & 0.776 & & 0.735 & 0.729 & 0.682 \\
\hline 5 & 0.670 & 0.540 & 0.609 & & 0.675 & 0.637 & 0.538 \\
\hline 6 & 0.574 & 0.429 & 0.508 & & 0.641 & 0.599 & 0.447 \\
\hline 7 & 0.484 & 0.315 & 0.404 & & 0.610 & 0.553 & 0.374 \\
\hline 8 & 0.418 & 0.295 & 0.396 & & 0.583 & 0.535 & 0.332 \\
\hline 9 & 0.347 & 0.259 & 0.379 & & 0.571 & 0.519 & 0.296 \\
\hline 10 & 0.278 & 0.161 & 0.285 & & 0.540 & 0.489 & 0.228 \\
\hline 11 & 0.198 & 0.091 & 0.202 & & 0.503 & 0.437 & 0.175 \\
\hline 12 & 0.144 & 0.011 & 0.060 & & 0.471 & 0.203 & 0.027 \\
\hline
\end{tabular}

The results presented in table VI confirm the findings of Fama that the forward rate is not as good a predictor of the future spot rate as is the current spot rate. Adjusting the forward rates for the volatility related liquidity premia does improve the $\mathrm{R}$-squares especially for the period before 1979/9. After the adjustment, the forward rates provide forecsts for the future spot rates almost as good as the current spot rate. However, the magnitude of the $\mathrm{R}$-squares also indicates that the premium part is of second order importance. In other words, the ENR model seems to be working, but it is mainly for fine tunning as the bill market volatility is usually low.

Finally we compare directly the relative performance of the premium-adjusted forward rate and the current spot rate as predictors for future spot rates by putting simultaneously the premium-adjusted forward rate and the current spot rate in the forecasting equation for future spot rate. The regression equation is: 


$$
r_{t+n-1}^{(1)}=b_{0}+b_{1} \cdot\left[f_{t}^{(n)}-L_{t}^{(n)}\right]+b_{2} \cdot r_{t}^{(1)}+e_{t+n-1}
$$

If the ENR model is appropriate, then in principle, the current spot rate should have no additional predictive power for the future spot rate beyond that of the premium-adjusted forward rate. In other words, the coefficient $b_{2}$ in equation (17) should be small and insignificant. The regression results are presented in table VII below.

Table VII

\begin{tabular}{|c|c|c|c|c|c|c|c|c|}
\hline \multirow[b]{3}{*}{$\mathbf{n}$} & \multicolumn{8}{|c|}{$r_{t+n-1}^{(1)}=b_{0}+b_{1} \cdot\left[f_{t}^{(n)}-L_{t}^{(n)}\right]+b_{2} \cdot r_{t}^{(1)}+e_{t+n-1}$} \\
\hline & \multicolumn{3}{|c|}{$64 / 8-79 / 8$} & \multicolumn{4}{|c|}{$64 / 8$} & \multirow[b]{2}{*}{$\mathrm{R}^{2}$} \\
\hline & $\mathrm{b}_{0}$ & $b_{1}$ & $b_{2}$ & $\mathrm{R}^{2}$ & $\mathrm{~b}_{0}$ & $b_{1}$ & $\mathrm{~b}_{2}$ & \\
\hline 2 & $\begin{array}{l}0.0117 \\
(0.013)\end{array}$ & $\begin{array}{l}0.3622 \\
(0.083)\end{array}$ & $\begin{array}{l}0.6185 \\
(0.084)\end{array}$ & 0.895 & $\begin{array}{l}0.0207 \\
(0.011)\end{array}$ & $\begin{array}{l}0.5769 \\
(0.087)\end{array}$ & $\begin{array}{l}0.3877 \\
(0.086)\end{array}$ & 0.909 \\
\hline 3 & $\begin{array}{l}0.0262 \\
(0.022)\end{array}$ & $\begin{array}{l}0.2790 \\
(0.110)\end{array}$ & $\begin{array}{l}0.6710 \\
(0.118)\end{array}$ & 0.823 & $\begin{array}{l}0.0442 \\
(0.022)\end{array}$ & $\begin{array}{l}0.3798 \\
(0.110)\end{array}$ & $\begin{array}{l}0.5436 \\
(0.109)\end{array}$ & 0.827 \\
\hline 4 & $\begin{array}{l}0.0225 \\
(0.027)\end{array}$ & $\begin{array}{l}0.6117^{\prime} \\
(0.121)\end{array}$ & $\begin{array}{l}0.3431 \\
(0.124)\end{array}$ & 0.789 & $\begin{array}{l}0.0805 \\
(0.032)\end{array}$ & $\begin{array}{l}0.1193 \\
(0.129)\end{array}$ & $\begin{array}{l}0.7477 \\
(0.124)\end{array}$ & 0.736 \\
\hline 5 & $\begin{array}{l}0.0379 \\
(0.042)\end{array}$ & $\begin{array}{l}0.3217 \\
(0.107)\end{array}$ & $\begin{array}{l}0.6055 \\
(0.126)\end{array}$ & 0.695 & $\begin{array}{l}0.1218 \\
(0.041)\end{array}$ & $\begin{array}{c}-.1032 \\
(0.133)\end{array}$ & $\begin{array}{l}0.9013 \\
(0.128)\end{array}$ & 0.676 \\
\hline 6 & $\begin{array}{l}0.0580 \\
(0.052)\end{array}$ & $\begin{array}{l}0.3037 \\
(0.144)\end{array}$ & $\begin{array}{l}0.5836 \\
(0.165)\end{array}$ & 0.599 & $\begin{array}{l}0.1481 \\
(0.048)\end{array}$ & $\begin{array}{c}-.1806 \\
(0.136)\end{array}$ & $\begin{array}{l}0.9345 \\
(0.132)\end{array}$ & 0.647 \\
\hline 7 & $\begin{array}{l}0.0947 \\
(0.064)\end{array}$ & $\begin{array}{l}0.2221 \\
(0.160)\end{array}$ & $\begin{array}{l}0.5910 \\
(0.204)\end{array}$ & 0.499 & $\begin{array}{l}0.1648 \\
(0.057)\end{array}$ & $\begin{array}{c}-.1631 \\
(0.139)\end{array}$ & $\begin{array}{l}0.8883 \\
(0.132)\end{array}$ & 0.616 \\
\hline 8 & $\begin{array}{l}0.0942 \\
(0.071)\end{array}$ & $\begin{array}{l}0.3502 \\
(0.163)\end{array}$ & $\begin{array}{l}0.4591 \\
(0.205)\end{array}$ & 0.459 & $\begin{array}{l}0.1931 \\
(0.063)\end{array}$ & $\begin{array}{l}-.2746 \\
(0.159)\end{array}$ & $\begin{array}{l}0.9526 \\
(0.156)\end{array}$ & 0.599 \\
\hline 9 & $\begin{array}{l}0.1091 \\
(0.077)\end{array}$ & $\begin{array}{l}0.4322 \\
(0.181)\end{array}$ & $\begin{array}{l}0.3502 \\
(0.228)\end{array}$ & 0.419 & $\begin{array}{l}0.1847 \\
(0.068)\end{array}$ & $\begin{array}{l}-.1689 \\
(0.157)\end{array}$ & $\begin{array}{l}0.8604 \\
(0.157)\end{array}$ & 0.580 \\
\hline 10 & $\begin{array}{l}0.1341 \\
(0.086)\end{array}$ & $\begin{array}{l}0.3387^{\prime} \\
(0.134)\end{array}$ & $\begin{array}{l}0.4007 \\
(0.210)\end{array}$ & 0.363 & $\begin{array}{l}0.1929 \\
(0.076)\end{array}$ & $\begin{array}{c}-.1311 \\
(0.143)\end{array}$ & $\begin{array}{l}0.8110 \\
(0.155)\end{array}$ & 0.548 \\
\hline 11 & $\begin{array}{l}0.1566 \\
(0.096)\end{array}$ & $\begin{array}{l}0.3178 \\
(0.122)\end{array}$ & $\begin{array}{l}0.3837 \\
(0.224)\end{array}$ & 0.285 & $\begin{array}{l}0.2100 \\
(0.081)\end{array}$ & $\begin{array}{c}-.1216 \\
(0.143)\end{array}$ & $\begin{array}{l}0.7694 \\
(0.161)\end{array}$ & 0.510 \\
\hline 12 & $\begin{array}{l}0.2091 \\
(0.115)\end{array}$ & $\begin{array}{l}0.1524 \\
(0.102)\end{array}$ & $\begin{array}{l}0.4395 \\
(0.252)\end{array}$ & 0.183 & $\begin{array}{l}0.2400 \\
(0.085)\end{array}$ & $\begin{array}{l}-.1594 \\
(0.088)\end{array}$ & $\begin{array}{l}0.7463 \\
(0.147)\end{array}$ & 0.495 \\
\hline
\end{tabular}

(The numbers in parentheses are asymptotic standard errors with the Hansen-Hodrick autocorrelation correction) 
For the sub-sample period ending August 1979, the estimated coefficient $b_{1}$ for the premium-adjusted forward rate is significant for most $n$. And, the estimated coefficient $b_{2}$ for the current spot rate is far from being close to one which is the value predicted by a simple random walk model for spot rate. The highest $b_{2}$ we got in that sub-sample period is only 0.6710 for $n=3$ and the lowest is 0.3431 for $n=4$. The results strongly suggest that the premium-adjusted forward rate has power in predicting future spot rate. For the full sample period, the estimated coefficient $b_{2}$ is also smaller than what one would have expected if the random walk model were true (especially for $n=2,3$ ). However, the coefficient $b_{1}$ is significant only for $n=2$ and $n=3$. It is likely that the change in operating procedure by the Federal Reserve in 1979 did produce a structural change in the behavior of the bill market which shows up very clearly in these comparisons.

\section{CONCLUSION}

In this paper, we reexamine the Factor ARCH model for Treasury bills introduced by Engle, $\mathrm{Ng}$, and Rothschild (1990). We investigate: (1) whether or not the model can generate plausible shapes for the yield curve, (2) the relationship between the level of volatility in the bill market and the position and shape of the yield curve, and (3) whether or not adjusting the forward rates using the volatility related liquidity premia will help in predicting future spot rates. We found that the combined effect of the expectation component and the premium component can produce yield curves of the commonly observed shapes. However, the yield curve is more likely to be monotonically increasing when volatility is high. When volatility is low, the premium component is not very important relative to the expectation component. Hence, the shape of the yield curve is determined mostly by expectations about future spot rates. Furthermore, adjusting the forward rate for the volatility related liquidity premium can improve its performance as a predictor for future spot rate at least for the period from August 1964 to August 1979. 


\section{APPENDIX}

The relationships among holding return, term premium, yield to maturity, forward rate and liquidity premium

Let $B_{t}^{(n)}$ be the price at time $t$ of a pure discount bond paying 1 dollar at time $t+n$.

The holding period return of the Treasury bill from time $t-1$ to time $t$ is given by

$$
R_{t}^{(n)} \equiv \log B_{t}^{(n-1)}-\log B_{t-1}^{(n)}
$$

The excess return from holding a n-period pure discount bond over the one month bill rate is

(A2)

$$
y_{t}^{(n)} \equiv R_{t}^{(n)}-R_{t}^{(1)}
$$

The term premium from holding a $n$-period pure discount bond is

$$
\mu_{\mathrm{t}}^{(\mathrm{n})} \equiv \mathrm{E}_{\mathrm{t}-1}\left(\mathrm{y}_{\mathrm{t}}^{(\mathrm{n})}\right)
$$

Solving forward, we get (for $n=2,3, \ldots$ )

$$
\begin{aligned}
\log B_{t}^{(n)} & =E_{t}\left(\log B_{t+1}^{(n-1)}\right)-R_{t+1}^{(1)}-\mu_{t+1}^{(n)} \\
& =E_{t}\left(\log B_{t+2}^{(n-2)}\right)-E_{t}\left(R_{t+2}^{(1)}\right)-E_{t}\left(\mu_{t+2}^{(n-1)}\right) \\
& \quad-R_{t+1}^{(1)}-\mu_{t+1}^{(n)} \\
& \vdots \\
& =0-\sum_{j=1}^{n} E_{t}\left(R_{t+j}^{(1)}\right)-\sum_{j=1}^{n} E_{t}\left(\mu_{t+j}^{(n-j+1)}\right)
\end{aligned}
$$

The yield to maturity at time $t$ of an $n$-period pure discount bond is

$$
r_{t}^{(n)} \equiv-\log B_{t}^{(n)} / n
$$

Since, the rate of return of a one-period pure discount bond from time $t$ to time $t+1$, $R_{t+1}^{(1)}$, is by definition equal to the yield to maturity of a one-period bond at time $t, r_{t}^{(1)}$, the expression for yield to maturity is therefore

$$
\begin{gathered}
r_{t}^{(n)} \equiv E_{t}\left(A_{t+1}^{(n)}\right)+E_{t}\left(T_{t+1}^{(n)}\right) \\
\text { where, } A_{t+1}^{(n)} \equiv \frac{1}{n} \cdot \sum_{j=1}^{n} R_{t+j}^{(1)}=\frac{1}{n} \cdot \sum_{j=0}^{n-1} r_{t+j}^{(1)} \\
T_{t+1}^{(n)} \equiv \frac{1}{n} \cdot \sum_{j=1}^{n} \mu_{t+j}^{(n-j+1)}
\end{gathered}
$$

The one period forward rate at time for the period from time $n-1$ to time $n$ is

$$
\begin{aligned}
f_{t}^{(n)} \equiv & \log B_{t}^{(n-1)}-\log B_{t}^{(n)} \\
& =n \cdot r_{t}^{(n)}-(n-1) \cdot r_{t}^{(n-1)}
\end{aligned}
$$

Using the expression for $r_{t}^{(n)}$, we can write 
(A8)

$$
f_{t}^{(n)}=E_{t}\left(r_{t+n-1}^{(1)}\right)+\left[n \cdot E_{t}\left(T_{t+1}^{(n)}\right)-(n-1) \cdot E_{t}\left(T_{t+1}^{(n-1)}\right)\right]
$$

The corresponding liquidity premium is therefore

$$
\text { (A9) } \quad \begin{aligned}
L_{t}^{(n)} & \equiv f_{t}^{(n)}-E_{t}\left(r_{t+n-1}^{(1)}\right) \\
& =n \cdot E_{t}\left(T_{t+1}^{(n)}\right)-(n-1) \cdot E_{t}\left(T_{t+1}^{(n-1)}\right)
\end{aligned}
$$




\section{REFERENCES}

Bollerslev, Tim (1986), "Generalized Autoregressive Conditional Heteroskedasticity", JOURNAL OF ECONOMETRICS, 31, 307-327.

Breeden, D. (1979), "An Intertemporal Asset Pricing Model with Stochastic Consumption and Investment Opportunities," JOURNAL OF FINANCIAL ECONOMICS, 7, pp 265-296.

Brown, S. and P. Dybvig (1986), "The Empirical Implications of the Cox, Ingersoll, Ross Theory of the Term Structure of Interest Rates," THE JOURNAL OF FINANCE, vol XLI, no.3.

Campbell, J. (1987), "Stock Returns and the Term Structure," JOURNAL OF FINANCIAL ECONOMICS, 18, 373-399.

Diebold, F.S. and M. Nerlove (1989), "The Dynamics of Exchange Rate Volatility: A Multivariate Latent Factor ARCH Model," JOURNAL OF APPLIED ECONOMETRICS, 4, pp 1-22.

Dobson, S.W., R. Sutch, and D. Vanderford (1976), "An Evaluation of Alternative Empirical Models of the Term Structure of Interest Rates," THE JOURNAL OF FINANCE, vol XXXI, no.4.

Engle, R. (1982), "Autoregressive Conditional Heteroscedasticity with Estimates of the Variance of U.K. Inflation," ECONOMETRICA, 50, pp 987-1008.

Engle, R., D. Lilien, and R. Robins (1987), "Estimating Time Varying Risk Premia in the Term Structure: The ARCH-M Model," ECONOMETRICA, 55, pp 391-408.

Engle, R., V. Ng, and M. Rothschild (1990), "Asset Pricing with a Factor ARCH Covariance Structure: Empirical Estimates for Treasury Bills," JOURNAL OF ECONOMETRICS 45, pp 213-237.

Fama, E. (1976a), "Forward Rates as Predictors of Future Spot Rates," JOURNAL OF FINANCIAL ECONOMICS, 3, pp 361-377.

Fama, E. (1976b), "Inflation Uncertainty and Expected Returns on Treasury Bills," JOURNAL OF POLITICAL ECONOMY, vol 84, no.3.

Fama, E. (1984a), "Term Premiums in Bond Returns," JOURNAL OF FINANCIAL ECONOMICS, 13, 529-546.

Fama, E. (1984b), "The Information in the Term Structure," JOURNAL OF FINANCIAL ECONOMICS, 13, pp 509-528.

Hansen, L.P. and R. Hodrick (1980), "Forward Exchange Rates as Optimal Predictors of Future Spot Rates: An Econometric Analysis," JOURNAL OF POLITICAL ECONOMY, vol 88 , no. 5 . 
Lauterbach, B. (1989), "Consumption Volatility, Production Volatility, Spot-Rate Volatility, and the Returns on Treasury Bills and Bonds, "JOURNAL OF FINANCIAL ECONOMICS, 24, pp 155-179.

Lin, W.L. (1989), "Alternative Estimators for Factor GARCH Models - A Monte Carlo Comparison," Department of Economics, University of Wisconsin at Madison.

Merton, R. (1973), "An Intertemporal Capital Asset Pricing Model," ECONOMETRICA $41,867-887$.

McCulloch, J.H. (1975), "An Estimate of the Liquidity Premium," JOURNAL OF POLITICAL ECONOMY, vol 83, no.1.

McCulloch, J.H. (1987), "The Monotonicity of the Term Premium: A Closer Look," JOURNAL OF FINANCIAL ECONOMICS, 18, pp 185-192.

Melino, A. (1983), "The Term Structure of Interest Rates: Evidence and Theory," memo, Department of Economics, University of Toronto.

Nelson, C. and A. Siegel (1987), "Parsimonious Modeling of Yield Curves," THE JOURNAL OF BUSINESS, vol 60, no.4.

Ross, S. (1976), "The Arbitrage Theory of Capital Asset Pricing," JOURNAL OF ECONOMIC THEORY, 13, pp 341-360.

Singleton, K. (1980), "Expectations Models of the Term Structure and Implied Variance Bounds," JOURNAL OF POLITICAL ECONOMY, vol 88, no.6. 
</ref_section> 